\title{
EFFECT OF USING MIXTURE OF DRAINGE AND FRESH WATER ON DRIP IRRIGATION SYSTEMS
}

\author{
Younis, Samir M. ",Saad Fathallah Ahemed", \\ Moustfa Abou El-Khair* and Ahmed M. Ibrahim**
}

ABSTRACT

The agricultural irrigated area depends on the availability of sufficient quantities of suitable quality of irrigation water, but with the large scale increases in agriculture and the shortage in good quality water resources, lead to the necessity of Using the available water in the most proper way. For that this study was designed to discuss the effect of the type of water on the soil, crops and its effect on the emitters.

A field experiment has been applied to study the effect of different irrigation water treatments. Therefore four treatments of irrigation water $(100 \%, 80 \%, 50 \%$ and 0\%) irrigation water and the rest is drainage water.

Four types of emitters, were chosen to represent the most common types of emitters which exists in the local market, and used in irrigating the vegetable crops, online emitters as HO, inline emitter as GR, pressure compensating emitters as KA and pressure compensating and self flushing as $M F$.

Results showed that the soil was affected by the irrigation water salinity. The water EC increased as well as the pH mainly for the $100 \%$ drainage water treatment and this influence decreased for the other three treatments. The MF emitter is the most stable emitter and had a Suitable application efficiency and has not been affected by the irrigation treatment, but its high price eliminate it's use in irrigation vegetable crops, therefore it can be cleared the GR emitter is the most suitable emitter while it came in the second place, but it is not that expensive and available for ordinary farmers.

And also the $80 \%$ irrigation water \& $20 \%$ drainage water can be used with little change in the yield than the yield of the irrigation water treatment.

** $\quad$ Agric. Eng. -Dept Faculty of Agric.- Alexandria University.

** $\quad$ Ministry of Agriculture. 


\section{INTRODUCTION}

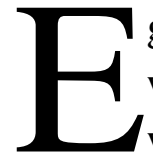
gypt now is having a direction to mix agricultural drainage water with irrigation water, especially in the lands which suffer from water shortage. This direction exists in the new lands, which have problems with water availability, causing fatal problems to the cultivated crops in these areas. The drainage water is available in these new lands beside the cultivated land, and it can be easily used with the existing modern irrigation systems in the area. One of the most important policies of the Ministry of Water Resources and Irrigation (MWRI) is blending of agriculture drainage water (low quality water) with irrigation water (Nile water), for covering larger cultivated areas. The most recent statistics and reports show that the agriculture sector is now benefiting from about 7 Billion $\mathrm{m}^{3}$ per year from agriculture drainage water mixed with the delta irrigation water.

In the new lands, the farmers use modem irrigation systems as sprinkler and drip irrigation, and most of them use drip irrigation system using different types of emitters. Some types of these emitters are self flushing, other types are pressure compensating, some of them are online emitters, and others are inline emitters. And the existence of salts may cause drop in the emitter discharge. Therefore it is necessary for the farmers to know which type can be used from each one of these emitters with minimal clogging problems.

The main objectives of this research is to study the effect of blending of agriculture drainage water with irrigation water, on the application efficiency of the drip irrigation system and to choose the suitable emitter type, to produce tomato crop production.

The irrigation methods are generally more efficient in terms of water use (FAO/RNEA, 1992), Hamdy (1999), reported that sprinkler irrigation systems are more affected by water quality than surface irrigation systems, primarily as a result of clogging orifices in sprinkler heads, potential leaf burns and phytotoxicity when water is saline and contains excessive toxic elements.

Bucks and Davis (1986) defined trickle irrigation as it is the slow application of water on, above, or beneath the soil by surface trickle, subsurface trickle, bubbler, spray, mechanical-move, and pulse systems. 
Water is applied as direct or continuous drops, tiny streams, through emitters or applicators placed along a water delivery line near the plant.

Bucks and Davis (1986), Illustrated that trickle irrigation system are typically defined in terms of installation method. emitter discharge rate, wetted soil surface area, or mode of operation. The six basic types of trickle irrigation system are the following:
a) Surface trickle system.
b) Subsurface trickle systems

Von Bernuth and Solomon (1986). reported that trickle irrigation offers several potential advantages over other irrigation systems, The primary one being the precise application of water from the emitter system. Many factors contribute to the overall precision of water application, however, the most critical component of the system in this regard is probably the emitter.

Solomon (1979) developed a method to numerically represent the amount of unit-to-unit variation in emitter flow rate due to the manufacturing processes.

\section{MATERIALS AND METHODS}

Four types of emitters were selected to use in this study. These types are widely used in drip irrigation systems in Egypt especially in new lands. These emitters are commercially stated as a $4 \mathrm{I} / \mathrm{h}$.

\section{a) Locally made emitters:}

1- The (GR )emitter ( inline emitter).

2- The Homosa (HO) emitter (online emitter).

\section{b) Imported emitters:}

3- Micro flapper (MF) which is a pressure compensating and self flushing (online emitter) .

4- Katief (KA) which is pressure compensating (online emitter). From now and on, we will call them by initials as GR, HO, MF and KA respectively for this research.

The experimental drip irrigation system consists of four water line, each line has a plastic tank of $1 \mathrm{~m}^{3}$. All tanks are connected to the pump which is operated by a one horse power electric motor with the discharge rate of $30 \sim 40 \mathrm{~L} / \mathrm{s}$. A screen filter (130 mesh, \& $0.02 \mathrm{~m}$ inlet/outlet diameter) was used in the line. The filter was flushed out after each irrigation interval to assure its full performance. 
The laboratory tests were conducted on the emitters, under the study. The measurements taken were:

1- Mean discharge rate of each type of emitters.

2- Determining the coefficient of variation (CV) by Solomon (1979) equation:

The main goal of this experimental work was to measure the effect of using irrigation water mixed with drainage water on the drip irrigation system to produce tomato crop. The following four mixing ratios were used:

Location High quality water Low quality water
A $100 \%$ Irrigation water : $0 \%$ Drainage water
B $80 \%$ Irrigation water : $20 \%$ Drainage water
C $50 \%$ Irrigation water : $50 \%$ Drainage water
D $0 \%$ Irrigation water : $100 \%$ Drainage water

The experimental field was divided into four plots, each plot dimensions were $12 \mathrm{~m} \times 21 \mathrm{~m}$. The plot was divided into four strips, and each strip was considered for one specified emitter treatment, each treatment contained five laterals, each lateral dimensions was $12 \mathrm{~m}$ length and one meter width. Involving land preparation were plowing. harrowing and spraying of herbicides and fertilizers. The seedling type was Hybrid castle rock. The tomato plants were transplanted at the age of 30 days, The transplants for the plots were planted at the same time, and the water quantity and time for all treatments were also the same. The irrigation water schedule is listed in table (1) regarding the data:

i- The crop coefficient, $k_{c}$

ii- The maximum evapotranspiration during this period $\mathrm{ET}_{\text {omax }} \mathrm{mm} /$ day.

iii- The maximum amount of water required by the tree, $\mathrm{ET}_{\text {crop }} \mathrm{mm} /$ day.

iv- The irrigation time $\mathrm{T}$ at the different stages of the tomato tree $\mathrm{h} /$ day. Ismail (1996) stated that the equation of calculating the irrigation time is:

\section{Where:}

$$
\mathbf{T}=\left(\mathbf{E T}_{\text {crop }} \times \mathbf{A}\right) /\left(\mathbf{E} \mathbf{U} \times \mathbf{q}_{\text {avg }}\right)
$$

$\mathrm{T} \quad=$ Irrigation durations in Hrs., $\mathrm{A}=$ The area for each plant, $\mathrm{m}^{2}$.

$\mathrm{EU} \quad=$ The irrigation system efficiency.

$\mathrm{ET}_{\text {crop }}=$ water required by the tree $\mathrm{mm} /$ day.

$\mathrm{q}_{\text {avg }}=$ The average discharge of the emitters, $1 / \mathrm{h}$ 
The following properties of soil were measured:

1- electric conductivity (EC) (using EC meter).

2- $\mathrm{pH}$ of the soil solution (using $\mathrm{pH}$ meter).

3- Infiltration rate $(\mathrm{cm} / \mathrm{h})$.

4- Anions and cations in the soil solution. (a device to analyses the cations and anions called "Atomic")

Irrigation water (high quality) and drainage (low quality) water were analyzed monthly.

\section{The Physical properties:}

i- Electric conductivity (EC).

ii- $\mathrm{pH}$

iii- Total dissolved salts (TDS)

\section{The Chemical properties were:}

\section{i- Anions , ii- Cations.}

\section{Biological properties for water analyzed in used:}

i- Total bacterial count.

ii- Total coliform bacteria.

iii- Coliform organisms presumptive.

The emitter discharge rate was measured once every month intervals, as well as measuring application efficiency, at a fixed pressure of one bar, for each strip within plots

\section{1-The water analysis:}

\section{RESULT AND DISCUTION}

Samples of water used were analyzed chemically, physically, and biologically during the experiment as recommended by FAO paper NO.29 (1985). The average values are presented in Table (2)

\section{2- Blended water quality}

The quality of blended water was determined by the following equation according to the FAO (1985), Irrigation paper NO.29 :

\section{Where:}

\section{Concentration of blended water $=($ A.X $)+($ B. Y $)$}
$\mathrm{A}=$ is the concentration of water A (ppm),
$\mathrm{X}=$ is the proportion of water A used,
$\mathrm{B}=$ is the concentration of water $\mathrm{B}(\mathrm{ppm})$,
$\mathrm{Y}=$ is the proportion of water $\mathrm{B}$ used 
Table (1): The irrigation water schedule throughout the experimental period

\begin{tabular}{|c|c|c|c|c|c|}
\hline Stage & I & II & III & IV & 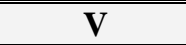 \\
\hline Date & $1 / 8-30 / 8$ & $31 / 8-4 / 10$ & $5 / 10-3 / 11$ & $4 / 11-3 / 12$ & $4 / 12-25 / 12$ \\
\hline $\mathbf{K}_{\mathbf{c}}$ & 0.4 & 0.7 & 1.1 & 0.8 & 0.6 \\
\hline ET $_{\text {o max }} \mathrm{Mm} /$ day & 7.7 & 5.9 & 5.9 & 3.5 & 3.8 \\
\hline $\mathbf{E T}_{\text {crop }} \mathrm{Mm} / \mathrm{day}$ & 3.1 & 4.1 & 6.2 & 2.8 & 2.3 \\
\hline T $\quad$ h/day & 0.5 & 0.6 & 0.8 & 0.4 & 0.4 \\
\hline
\end{tabular}

Table (2): Irrigation and drainage water characteristics

\begin{tabular}{|c|c|c|}
\hline Paramter* & Irrigation & Drainage water \\
\hline \multicolumn{3}{|c|}{ Physical analysis } \\
\hline $\mathrm{EC}(\mathrm{ds} / \mathrm{m})$ & 0.6 & 2.6 \\
\hline $\mathrm{pH}$ & 7.0 & 7.7 \\
\hline TDS (ppm) & 401.3 & 1633.9 \\
\hline \multicolumn{3}{|c|}{ Chemical analyses } \\
\hline SAR & 1.3 & 6.7 \\
\hline \multicolumn{3}{|l|}{ Cations: $(\mathrm{meq} / \mathrm{l})$} \\
\hline Ca & 2.1 & 4.2 \\
\hline $\mathrm{Mg}$ & 1.3 & 5.2 \\
\hline $\mathrm{Na}$ & 1.2 & 14.5 \\
\hline $\mathrm{K}$ & 0.2 & 0.7 \\
\hline \multicolumn{3}{|l|}{ Anions: (meq/l) } \\
\hline $\mathrm{HCO} 3$ & 3.5 & 15.0 \\
\hline $\mathrm{Cl}$ & 1.4 & 9.2 \\
\hline SO4 & 0.4 & 0.6 \\
\hline \multicolumn{3}{|c|}{$\begin{array}{ll}\text { Biological analyses }(\mathrm{cfu} / \mathbf{1 0 0 m l}) \\
\end{array}$} \\
\hline Total Bacterial & 54000 & 36000 \\
\hline Total Coliform bacteria & 427 & 363 \\
\hline Confirmed coliform bacteria & 299 & 291 \\
\hline Confirmed feceal streptococci & 145 & 242 \\
\hline
\end{tabular}

* Average values during the experiment duration

Table (3): The average quality of blended water throughout the whole season

\begin{tabular}{|l|c|c||}
\hline \multirow{2}{*}{\multicolumn{1}{|c|}{ Treatment }} & \multicolumn{2}{c|}{ Concentration of blended water } \\
\cline { 2 - 3 } & $\mathbf{M e} /$ lit & ppm \\
\hline 100\% irrigation water & 0.6 & 401.3 \\
\hline 80\% irrigation water + 20\% drainage water & 1.0 & 647.7 \\
\hline 50\% irrigation water + 50\% drainage water & 1.6 & 1017.6 \\
\hline 100\% drainage water & 2.6 & 1633.9 \\
\hline
\end{tabular}

Table (4): The data obtained from the laboratory test to determine the coefficient of manufacturing variation of emitter

\begin{tabular}{||l|c|c|c|c||}
\hline \multirow{2}{*}{ Emitter } & \multicolumn{4}{|c||}{ Discharage rate, $\mathbf{l} / \mathbf{h}$} \\
\cline { 2 - 5 } & MF & KA & GR & HO \\
\hline Average** & 3.81 & 3.97 & 4.01 & 4.15 \\
\hline S & 0.043 & 0.135 & 0.172 & 0.191 \\
\hline $\mathbf{V}^{*}$ & 0.011 & 0.034 & 0.043 & 0.046 \\
\hline
\end{tabular}

$* \mathbf{v}=$ Coefficient of manufacturing variation.

** The average for 30 reading

Misr J. Ag. Eng., April 2010 
The concentration can be expressed either meq/ or ppm. Table (3) represents the data calculated using the above equation for the blended water, during the whole season.

\section{3- Emitter performance measurements:}

A sample of 30 emitters of each type was selected randomly, and tested at pressure of 1 bar.

$$
\mathbf{V}=\mathbf{S} / \mathbf{M}
$$

as:

$\mathbf{V}$ is the coefficient of manufacturing variation

$\mathbf{S}$ is the standard deviation of the discharge rate a sample of 30 emitters.

$\mathbf{M}$ is the mean discharge rate of the emitters $(1 / \mathrm{h})$

Table (4) shows that the data obtained from the laboratory tests for. determining the coefficient of manufacturing variation for each emitter type. Calculations showed that the MF emitter had a coefficient of manufacturing variation value that is 0.011 , which is a good grade. The values of the coefficient of manufacturing variation for the other three emitters were $0.034,0.043$, and 0.046 , for KA, GR, and HO emitters, respectively.

Another experiments were conducted in order to calculate the $\mathrm{x}$ valueemission exponent- (Wu and Gitlin (1974), Howell and Hiller (1974) and Karmeli (1977), for the four emitters, table (5), in the following equation:

$\mathrm{k}$ is the emitter flow $(1 / \mathrm{h})$,

$$
\mathbf{q}=\mathbf{K h}^{\mathbf{x}}
$$

$\mathrm{k}$ is the constant of proportionality,

$\mathrm{h}$ is the pressure head at the emitter $(\mathrm{m})$,

$\mathrm{x}$ is the emitter exponent.

Table (5): The data obtained from the experiments on the four emitter types:

\begin{tabular}{|l|c|c|c|c|}
\hline Emitter & Type & Norminal flow $\mathbf{~ / h}$ & $\mathbf{K}$ & $\mathbf{X}$ \\
\hline MF & Online & 3.8 & 3.8 & 0.003 \\
\hline KA & Online & 3.97 & 3.7 & 0.042 \\
\hline GR & Inline & 4.0 & 4.0 & 0.497 \\
\hline HO & Online & 4.1 & 4.1 & 0.029 \\
\hline
\end{tabular}

\section{4- Emitter performance under different water treatments:}

Figure (1) shows that in the irrigation water treatment the MF emitter is 
the most sustainable emitter, and almost the three types MF, KA, GR have steady discharges compared with the $\mathrm{HO}$ emitter as its discharge decreased greatly than its initial value gradually. Figure (2) shows that in case of using $80 \%$ Irrigation water, and $20 \%$ drainage water, there was no effect on the emitter discharge rate.

Figure (3) shows that in the 50\% irrigation water and 50\% drainage water treatment, the MF was still having a steady discharge, showing high performance rate than the other three emitters regardless the water quality degradation, while the other three emitters were effected simultaneously, showing different response to water quality, but strongly affected by it. Figure (4) shows the drainage water treatment showed the same results as the $50 \%$ irrigation water but with slight decrease in the discharge rate.

In general, the results showed that the micro flapper (MF) emitter is the most sustainable emitter among the four types. This is due to that this type is pressure compensating, self-flushing, and with a minimum coefficient of manufacturer variation, compared with the other three types. If we could list the emitters according to its discharge response to water quality, the list will be: a) Micro-flopper (MF) ， b) GR ， c) Katief (KA) , d) Homosa (HO).

But on the other hands the list price of the MF emitter is about $0.42 \mathrm{LE} / \mathrm{emitter}$, which is so expensive from the economical prospective. Though we can choose the GR emitter as it is the second emitter in sustainability of its discharge, and it is cheaper than the MF emitter as the price of $1 \mathrm{~m}$ of GR pipe line equals about $0.39 \mathrm{LE}$ ( $1 \mathrm{~m}$. of GR pipeline contains two emitters). The Katief (KA) emitter also has a minimum coefficient of manufacturer variation value, but still has a very quick response to water quality, in spite of it is self compensating.

This shows that the relationship between emitter discharge rate and operation time can be represented by a straight line equation. This equation could be helpful in calculating the life time of each type of emitters under different water conditions (this equations are reliable within this range of water treatments). In order to predict the service life of emitter or the time after which it will be completely blocked. 


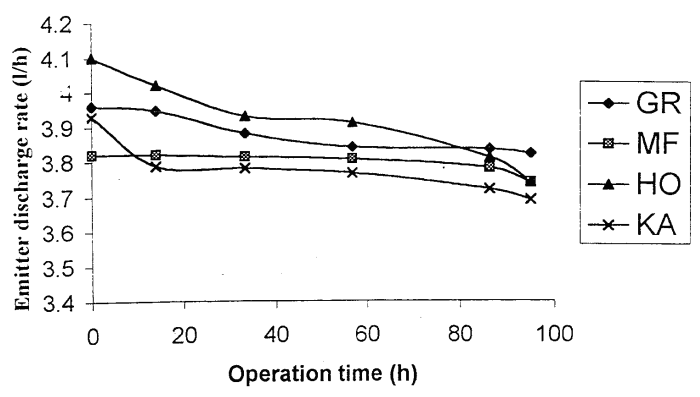

Fig (1): Average discharge rate for different emitter types. Using $100 \%$ irrigation water

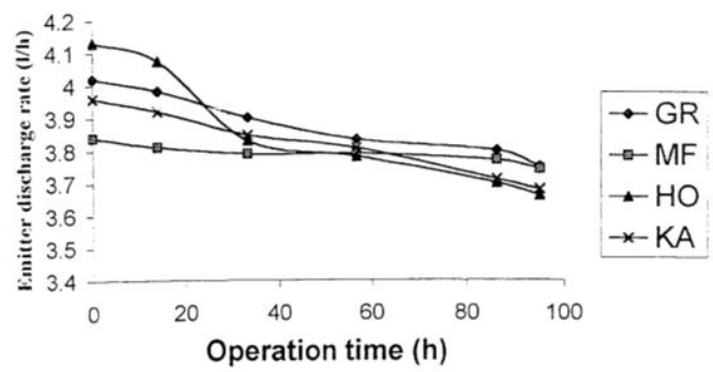

Fig (2): Average discharge rate foe different emitter type using $80 \%$ irrigation water and $20 \%$ drainage water treatment

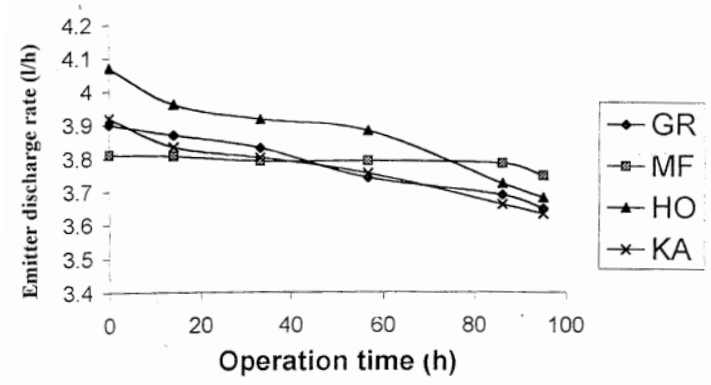

Fig (3): Average discharge rate foe different emitter type using 50\% irrigation water and $50 \%$ drainage water treatment

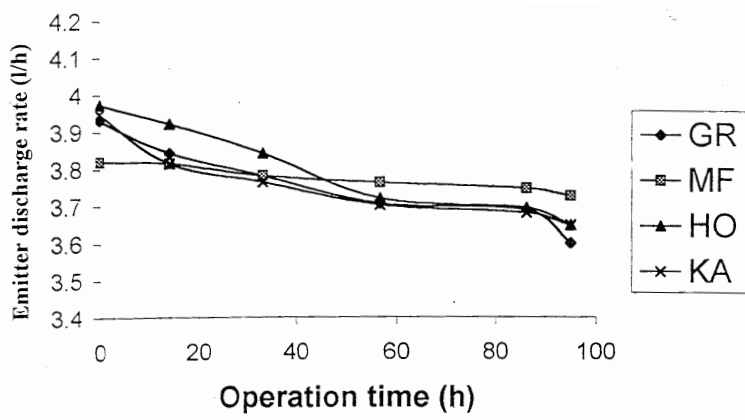

Fig (4): Average discharge rate foe different emitter type using $100 \%$ drainage water treatment 
For example from the equation of the MF emitter under irrigation water, we can say that this emitter will work for about 5500 hours before it will be completely blocked. While it is preferable to maintain the system and reinstall the emitters after reaching $50 \%$ of its discharge, this will be after about 2720 operation hours. This shows the high performance of the MF emitter. When we calculate the same two operations times for the HO emitter under Irrigation water treatment will give 1200 , 600 hours respectively.

Figure (5) shows the high sustainability of MF emitter which behaves almost the same within a very small range of variation. Figure (6) shows that the GR emitter comes second, but it had a tremendously strong reaction to the drainage water treatment. This shows the high influence of water salinity on emitter's discharge rate. Figures (7) and (8) show that the $\mathrm{KA}, \& \mathrm{HO}$ emitters had a very strong reaction to all water treatments which was highly affected by the drainage water treatment. Still the previous degradation of emitters, according to the response to all water treatments, is the same.

\section{5- Emitter clogging evaluation:}

In order to determine the degree of emitter clogging, Sharaf et al (1998), stated the following equation:

\section{Where:}

$$
\mathbf{R}_{\mathbf{F}}=\left(\mathbf{q}_{\mathrm{m}} / \mathbf{q}_{\mathbf{p}}\right)
$$

$\mathrm{R}_{\mathrm{f}}=$ relative flow rate of emitter, dimensionless,

$\mathrm{q}_{\mathrm{m}}=$ the measured flow rate, $\mathrm{cm}^{3} / \mathrm{min}$, which is obtained from the coefficient of manufacturing variation experiment,

$\mathrm{q}_{\mathrm{p}}=$ predicted flow rate $\mathrm{cm}^{3} / \min$.

After conducting the experimental investigations, the $R_{f}$ values were calculated for each emitter type under each water treatment, table (8). These values give an idea and overview about the effect of water treatment on the emitters performance.

The values of the $\mathrm{R}_{\mathrm{f}}$ for the emitters types varies a lot for the HO, KA and GR emitters, these means that the three mentioned emitters are partially clogged due to the water treatments. While the MF emitters variations in the $\mathrm{R}_{\mathrm{f}}$ values were very small and can be neglected. 


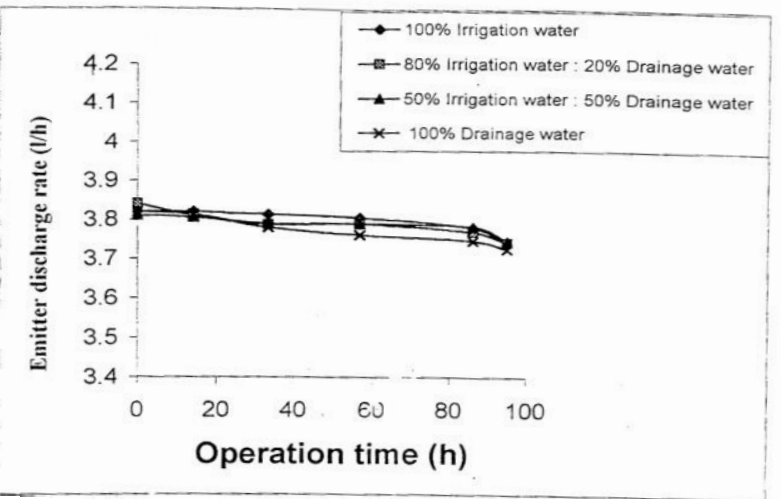

Fig (5): Effect of operating time on discharge rate of MF emitters under different water treatment

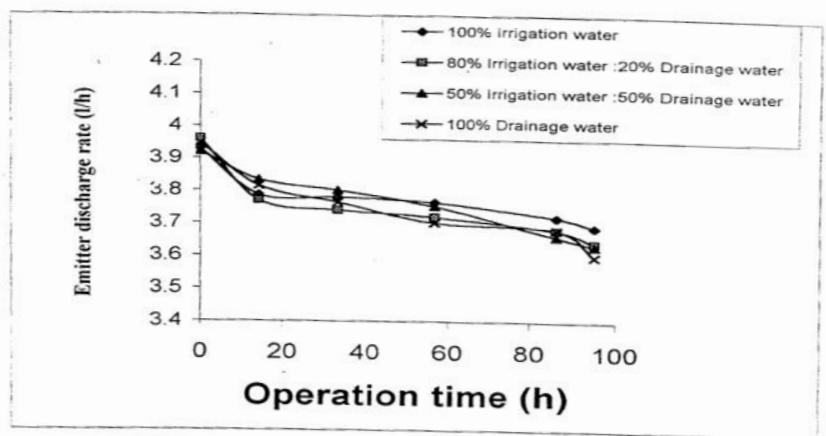

Fig (7): Effect of operating time on discharge rate of KA emitters under different water treatment

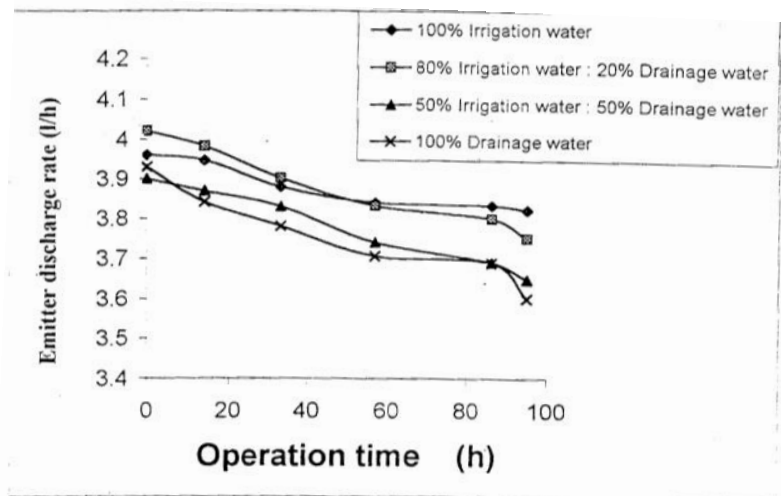

Fig (6): Effect of operating time on discharge rate of GR emitters under different water treatment

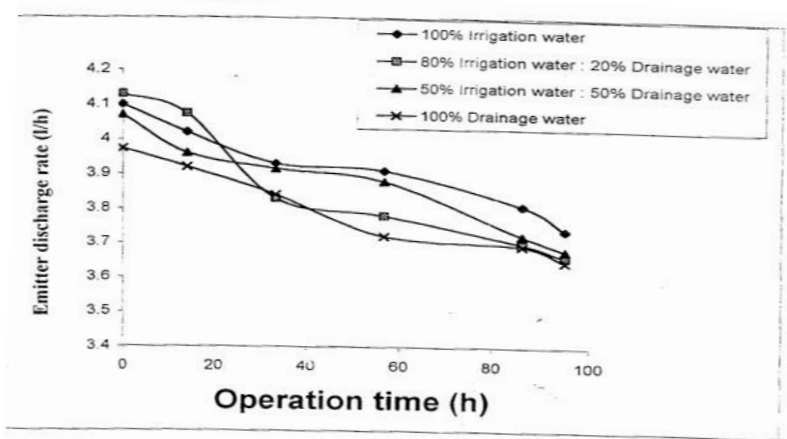

Fig (8): Effect of operating time on discharge rate of HO emitters under different water treatment 
This also shows that the water quality affects the discharge rate of emitters, causing partial blockage, leading to full blockage of emitter orifice if it is not well treated with chemicals, or replaced with new one in case of full blockage.

Taking into considerations these values, we can classify according to $\left(\mathrm{R}_{\mathrm{f}}\right)$ values listed in Table (6) as follows.
$1-\mathrm{MF}=0.980$
2- $\mathrm{GR}=0.925$
$3-\mathrm{KA}=0.920$
4- $\mathrm{HO}=$
0.888

\section{6- Emitter flow variation:}

In order to compute the flow variation for the trickle irrigation system emitters used in the experiment, based on the lateral line hydraulics, $\mathrm{Wu}$ and Leitlin (1975) equation could be used:

\section{Where:}

$$
\mathbf{q}_{\mathrm{var}}=100\left(1-\left(\mathbf{q}_{\min } / \mathbf{q}_{\max }\right)\right)
$$

$\mathrm{q}_{\mathrm{var}}=$ variation of emitter flow rate.

$\mathrm{q}_{\min }=$ minimum emitter flow rate.

$\mathrm{q}_{\max }=$ maximum emitter flow rate.

The values of $\mathrm{q}_{\mathrm{var}}$ are calculated from the data obtained from the field tests, which was used to calculate the system efficiency, This values are listed in table (7). Value of the $\mathrm{q}_{\mathrm{var}}$ for the MF emitter is only the one which is sustainable, while for the other types it shows that the variation in flow rate is high, and the $\mathrm{q}_{\mathrm{var}}$ increases by time. This indicates that variation in discharge rate of the emitters used in the experiment varies as the operational time of irrigation increases leading to emitter clogging.

\section{7- Uniformity of emitter flow rate:}

Comparing these values with the design emission uniformity EU, derived by Bralts (1975), will help in getting the emission uniformity for a proposed trickle irrigation system design. The equation is:

\section{Where:}

$$
\mathrm{EU}=100\left(1-\left[(1.27 \mathrm{v}) / \mathrm{e}^{0.5}\right]\right)\left(\mathrm{q}_{\min } / \mathrm{q}_{\mathrm{avg}}\right)
$$

$\mathrm{EU}=$ design emission uniformity.

$v=$ coefficient of manufacturing variation.

$\mathrm{e}=$ number of emitters / plant.

The data obtained from the laboratory tests, carried out on each emitter was used to compute the $(v)$. 
The EU values for the emitters under test are $98.60,95.85,95.10$ and 94.36 for MF, KA, GR and $\mathrm{HO}$ emitters respectively. This indicates that for the GR, KA and $\mathrm{HO}$ emitters the EU' differs slightly from the EU values showing that the emitters were affected by different water treatments. For the MF emitter these values were nearly the same, regardless the irrigation water treatments.

\section{8- Field Uniformity estimation:}

In order to encompasses significantly the irrigation system, FAO (1980), reported. that we can use the Field emission uniformity (EU) as follows:

\section{Where:}

$$
\mathbf{E U}=\left(\mathbf{q}_{\min } / \mathbf{q}_{\mathrm{avg}}\right) \times \mathbf{1 0 0}
$$

EU = Field emission uniformity.

$\mathrm{q}_{\mathrm{min}}=$ minimum discharge rate (average of the lowest fourth of all the emission readings is used as the minimum discharge).

$\mathrm{q}_{\text {avg }}=$ average emitter flow rate.

The field work was done according to the Soil Conservation Service National Engineering Handbook (1983). These data were collected in order to monitor the variation of the field uniformity according to different water treatments, and presented in Table (8).

\section{9- Application efficiency:}

From these data obtained on-field table(9), we can calculate the application efficiency of the irrigation system using, adopted from FAO (1980), which is:

$$
\mathbf{E a}=\mathbf{K}_{\mathrm{s}} \times \mathbf{E U}
$$

\section{Where:}

$\mathrm{K}_{\mathrm{s}}=$ coefficient $(<1)$ which expresses the water storage efficiency of the soil. And it takes into account unavoidable deep percolation as well as other losses.

Any other losses will considered to $b e=1$, and $K_{\mathrm{s}}=0.9$, then the application efficiency could be obtained by multiplying the data in table (11) by 0.9 .

The values of $\mathrm{EU}_{\mathrm{a}}$ show that $\mathrm{MF}$ emitter is almost stable under the irrigation treatments, throughout the operation time, while the other types had different characteristics. 
Table(6) The relative flow $R_{f}$ values of emitters under different water treatments

\begin{tabular}{|c|c|c|}
\hline Treatment & Emitter type & $R_{\text {f value }}$ \\
\hline \multirow{4}{*}{$100 \%$ irrigation water } & MF & 0.98 \\
\hline & $\mathrm{KA}$ & 0.93 \\
\hline & GR & 0.95 \\
\hline & $\mathrm{HO}$ & 0.90 \\
\hline \multirow{4}{*}{$\begin{array}{l}80 \% \text { irrigation water } \\
+20 \% \text { drainage water }\end{array}$} & MF & 0.98 \\
\hline & $\overline{K A}$ & 0.92 \\
\hline & GR & 0.94 \\
\hline & $\mathrm{HO}$ & 0.88 \\
\hline \multirow{4}{*}{$\begin{array}{l}50 \% \text { irrigation water } \\
+50 \% \text { drainage water }\end{array}$} & $\mathrm{MF}$ & 0.98 \\
\hline & $K A$ & 0.92 \\
\hline & GR & 0.91 \\
\hline & $\mathrm{HO}$ & 0.89 \\
\hline \multirow{4}{*}{$100 \%$ drainage water } & $\mathrm{MF}$ & 0.98 \\
\hline & $\mathrm{KA}$ & 0.91 \\
\hline & $\mathrm{GR}$ & 0.90 \\
\hline & $\mathrm{HO}$ & 0.88 \\
\hline
\end{tabular}

\section{Table(7) Variation in flow rate $\left(q_{v a r}\right)$ for the emitters under investigation}

\begin{tabular}{|c|c|c|c|c|c|}
\hline \multirow{2}{*}{ Treatment } & \multirow{2}{*}{$\begin{array}{l}\text { Emitter } \\
\text { type }\end{array}$} & \multicolumn{4}{|c|}{$\begin{array}{c}\text { Emitter flow variation } \\
\left(q_{\mathrm{var}} \%\right)\end{array}$} \\
\hline & & $\begin{array}{c}1^{\text {st }} \\
\text { Month }\end{array}$ & $\begin{array}{l}2^{\text {nd }} \\
\text { Month }\end{array}$ & Month & $4^{\text {th }}$ \\
\hline & MF & 5.13 & 5.73 & 7.33 & 7.09 \\
\hline $100 \%$ irrigation & $\mathrm{KA}$ & $11.6 \overline{3}$ & 10.73 & $12 . \overline{50}$ & 12.63 \\
\hline water & GR & 16.28 & 16.28 & 14.70 & 15.60 \\
\hline & $\mathrm{HO}$ & 16.00 & 14.63 & 14.29 & 12.59 \\
\hline $80 \%$ irrigation & MF & 6.15 & 7.12 & 6.45 & 7.67 \\
\hline water + & KA & 12.31 & 14.50 & 14.72 & 13.74 \\
\hline $20 \%$ drainage & GR & 17.45 & 16.36 & $15 . \overline{15}$ & $17 . \overline{15}$ \\
\hline water & $\mathrm{HO}$ & 17.42 & 15.62 & 17.33 & 17.25 \\
\hline $50 \%$ irrigation & MF & 6.12 & 6.45 & 7.12 & $6.8 \overline{1}$ \\
\hline water + & KA & 12.07 & 11.15 & 18.17 & 13.45 \\
\hline $50 \%$ drainage & GR & 16.45 & 16.84 & 17.81 & 19.53 \\
\hline water & $\mathrm{HO}$ & 16.87 & 16.24 & 17.87 & 12.45 \\
\hline & MF & 5.78 & 7.42 & 8.47 & 6.77 \\
\hline $100 \%$ drainage & KA & 11.79 & 12.76 & 17.54 & 13.47 \\
\hline water & GR & 17.13 & 18.84 & 19.74 & 18.71 \\
\hline & $\mathrm{HO}$ & 16.48 & 15.73 & 12.81 & 13.14 \\
\hline
\end{tabular}

Table(8) The field emission uniformity (EU') for the emitters under investigation

\begin{tabular}{|c|c|c|c|c|c|}
\hline \multirow{3}{*}{ Treatment } & \multirow{3}{*}{$\begin{array}{l}\text { Emitter } \\
\text { type }\end{array}$} & \multicolumn{4}{|c|}{$\begin{array}{l}\text { The field uniformity estimation } \\
\qquad\left(\mathrm{EU}_{\mathrm{a}} \%\right)\end{array}$} \\
\hline & & $1^{\text {st }}$ & $2^{\text {nd }}$ & $3^{\text {ra }}$ & $4^{27}$ \\
\hline & & Month & Month & Month & Month \\
\hline \multirow{4}{*}{$100 \%$ irrigation water } & $\mathrm{MF}$ & 97.78 & 97.91 & 97.61 & 96.34 \\
\hline & $\mathrm{KA}$ & 95.83 & 96.09 & 94.98 & 96.45 \\
\hline & GR & 92.54 & 91.18 & 92.60 & 92.81 \\
\hline & $\mathrm{HO}$ & 94.11 & 93.85 & 92.61 & 92.62 \\
\hline \multirow{4}{*}{$\begin{array}{l}80 \% \text { irrigation water }+ \\
20 \% \text { drainage water }\end{array}$} & MF & 97.40 & 97.78 & 97.25 & 96.33 \\
\hline & KA & 92.61 & 94.87 & 93.71 & 92.71 \\
\hline & $\mathrm{GR}$ & 90.70 & 91.52 & 92.91 & 92.52 \\
\hline & $\mathrm{HO}$ & 94.07 & 92.95 & 92.6 & 92.42 \\
\hline \multirow{4}{*}{$\begin{array}{l}50 \% \text { irrigation water + } \\
50 \% \text { drainage water }\end{array}$} & MF & 96.31 & 96.88 & 96.48 & 96.83 \\
\hline & KA & 90.39 & 90.24 & 92.63 & 92.40 \\
\hline & GR & 92.32 & 92.79 & 93.28 & $93 . \overline{48}$ \\
\hline & $\mathrm{HO}$ & 92.68 & 92.61 & 92.76 & 92.40 \\
\hline \multirow{4}{*}{$100 \%$ drainage water } & MF & 97.66 & 96.84 & 96.41 & 96.54 \\
\hline & $\mathrm{KA}$ & 92.59 & 92.17 & 92.32 & 92.66 \\
\hline & GR & 93.24 & 92.17 & 92.32 & 92.66 \\
\hline & $\mathrm{HO}$ & 92.26 & 91.29 & 91.86 & 92.43 \\
\hline
\end{tabular}


Table(9) Tomato crop production under different water quality treatments and emitters under study

\begin{tabular}{|c|c|c|c|c|c|}
\hline Treatment & $\begin{array}{c}\text { Emitter } \\
\text { type }\end{array}$ & $\begin{array}{l}\text { Prod. } \\
\mathrm{Kg} / \mathrm{m}^{2}\end{array}$ & $\begin{array}{l}\text { Prod. } \\
\text { KG/tree }\end{array}$ & $\begin{array}{c}\text { Avg. tomato } \\
\text { Fruit weight } \\
\mathrm{Kg}\end{array}$ & $\begin{array}{l}\text { Avg. } \\
\text { Yield } \\
\text { Ton/Fed. }\end{array}$ \\
\hline \multirow{4}{*}{$\begin{array}{l}100 \% \text { irrigation } \\
\text { water }\end{array}$} & MF & 3.56 & 1.96 & 0.08 & 15.05 \\
\hline & $\mathrm{KA}$ & 3.35 & 1.90 & 0.08 & $14 . \overline{88}$ \\
\hline & GR & 2.87 & 1.59 & 0.08 & 12.05 \\
\hline & $\mathrm{HO}$ & 2.71 & 1.64 & 0.08 & 11.36 \\
\hline \multirow{4}{*}{$\begin{array}{l}80 \% \text { irrigation } \\
\text { water + } \\
20 \% \text { drainage } \\
\text { water }\end{array}$} & $\mathrm{MF}$ & 3.17 & 1.80 & 0.08 & 13.32 \\
\hline & $\mathrm{KA}$ & 2.88 & 1.70 & 0.08 & 12.10 \\
\hline & GR & 2.75 & 1.65 & 0.07 & 11.54 \\
\hline & $\mathrm{HO}$ & 2.43 & 1.52 & 0.09 & 10.21 \\
\hline \multirow{4}{*}{$\begin{array}{l}50 \% \text { irrigation } \\
\text { water + } \\
50 \% \text { drainage } \\
\text { water }\end{array}$} & $\mathrm{MF}$ & 2.86 & 1.916 & 0.09 & 12.01 \\
\hline & $\mathrm{KA}$ & 2.69 & 1.78 & 0.08 & 11.28 \\
\hline & GR. & 2.43 & 1.73 & 0.08 & 10.22 \\
\hline & $\mathrm{HO}$ & 2.32 & 1.55 & 0.09 & 9.72 \\
\hline \multirow{4}{*}{$\begin{array}{l}100 \text { drainage } \\
\text { water }\end{array}$} & $\mathrm{MF}$ & 1.87 & 1.30 & 0.08 & 7.85 \\
\hline & $\mathrm{KA}$ & 1.65 & 1.18 & 0.08 & 6.92 \\
\hline & GR. & 1.51 & 1.11 & 0.07 & 6.34 \\
\hline & $\mathrm{HO}$ & 1.34 & 1.04 & 0.08 & 5.64 \\
\hline
\end{tabular}

Table(10) The relationship between crop yield ( $Y$ ) and water yuaity (EC) with different types of emitters

\begin{tabular}{|l|l|l|}
\hline Emitter type & \multicolumn{1}{|c|}{ Equation } & Correlation $(r)$ \\
\hline MF & $Y=17.320-3.642 E C$ & -0.9937 \\
\hline KA & $Y=16.232-3.551 E C$ & -0.9846 \\
\hline GR & $Y=14.417-3.029 E C$ & -0.9810 \\
\hline HO & $Y=13.404-2.885 E C$ & -0.9698 \\
\hline
\end{tabular}


Table(11) Soil characteristics at the beginning of the experiment

\begin{tabular}{|c|c|c|c|c|c|c|c|c|c|c|c|c|}
\hline \multirow[t]{2}{*}{ Parameter } & \multicolumn{3}{|c|}{$100 \%$ irrigation water } & \multicolumn{3}{|c|}{$\begin{array}{l}80 \% \text { irrigation water } \\
+20 \% \text { drainage water }\end{array}$} & \multicolumn{3}{|c|}{$\begin{array}{l}50 \% \text { irrigation water } \\
+50 \% \text { drainage water }\end{array}$} & \multicolumn{3}{|c|}{$100 \%$ drainage water } \\
\hline & \multicolumn{3}{|c|}{ Depth in $\mathrm{cm}$} & \multicolumn{3}{|c|}{ Depth in $\mathrm{cm}$} & \multicolumn{3}{|c|}{ Depth in $\mathrm{cm}$} & \multicolumn{3}{|c|}{ Depth in $\mathrm{cm}$} \\
\hline Physical analysis & $0-20$ & $20-40$ & $40-60$ & $0-20$ & $20-40$ & $40-60$ & $0-20$ & $20-40$ & $40-60$ & $0-20$ & $20-40$ & $40-60$ \\
\hline $\begin{array}{l}\mathrm{EC}(\mathrm{ds} / \mathrm{m}) \\
\mathrm{PH}\end{array}$ & $\begin{array}{l}1.60 \\
7.80\end{array}$ & $\begin{array}{l}1.72 \\
7.66\end{array}$ & $\begin{array}{l}1.53 \\
7.67\end{array}$ & $\begin{array}{l}1.62 \\
7.90\end{array}$ & $\begin{array}{l}1.73 \\
7.67\end{array}$ & $\begin{array}{l}1.57 \\
7.68\end{array}$ & $\begin{array}{l}1.64 \\
7.88 \\
\end{array}$ & $\begin{array}{l}1.76 \\
7.68\end{array}$ & $\begin{array}{l}1.55 \\
7.58\end{array}$ & $\begin{array}{l}1.65 \\
7.76\end{array}$ & $\begin{array}{l}1.77 \\
7.66\end{array}$ & $\begin{array}{l}1.56 \\
7.88\end{array}$ \\
\hline \multicolumn{13}{|l|}{ Chemical analysis } \\
\hline $\begin{array}{l}\mathrm{Ca}^{++} \\
\mathrm{Mg}^{++} \\
\mathrm{K}^{+} \\
\mathrm{Na}^{+}\end{array}$ & $\begin{array}{l}4.40 \\
5.20 \\
0.24 \\
7.40\end{array}$ & $\begin{array}{l}5.00 \\
6.40 \\
0.54 \\
8.33\end{array}$ & $\begin{array}{l}3.80 \\
4.60 \\
0.23 \\
7.42\end{array}$ & $\begin{array}{l}4.10 \\
5.30 \\
0.25 \\
6.80\end{array}$ & $\begin{array}{l}3.60 \\
4.80 \\
0.40 \\
7.20\end{array}$ & $\begin{array}{l}2.80 \\
5.40 \\
0.30 \\
7.80\end{array}$ & $\begin{array}{l}4.30 \\
5.40 \\
0.33 \\
8.40\end{array}$ & $\begin{array}{l}3.90 \\
4.20 \\
0.42 \\
7.50\end{array}$ & $\begin{array}{l}3.00 \\
5.60 \\
0.38 \\
6.44\end{array}$ & $\begin{array}{l}4.20 \\
5.30 \\
0.26 \\
7.60\end{array}$ & $\begin{array}{l}4.80 \\
6.40 \\
0.39 \\
7.94\end{array}$ & $\begin{array}{l}3.40 \\
4.40 \\
0.27 \\
7.73\end{array}$ \\
\hline $\begin{array}{l}\text { Anions (meq /I) } \\
\mathrm{HCO}_{3}^{-} \\
\mathrm{Cl}^{-}\end{array}$ & $\begin{array}{l}1.20 \\
4.75\end{array}$ & $\begin{array}{l}1.80 \\
8.33\end{array}$ & $\begin{array}{l}2.10 \\
5.41\end{array}$ & $\begin{array}{l}1.24 \\
5.30\end{array}$ & $\begin{array}{l}1.89 \\
5.47\end{array}$ & $\begin{array}{l}2.00 \\
4.50\end{array}$ & $\begin{array}{l}1.40 \\
6.40\end{array}$ & $\begin{array}{l}1.84 \\
7.33 \\
\end{array}$ & $\begin{array}{l}2.30 \\
5.64\end{array}$ & $\begin{array}{l}1.37 \\
6.48\end{array}$ & $\begin{array}{l}1.90 \\
7.46\end{array}$ & $\begin{array}{l}2.25 \\
6.23\end{array}$ \\
\hline Infilt. rate $\mathrm{cm} / \mathrm{h}$ & \multicolumn{3}{|c|}{0.30} & \multicolumn{3}{|c|}{0.42} & \multicolumn{3}{|c|}{0.35} & \multicolumn{3}{|c|}{0.40} \\
\hline
\end{tabular}

\section{Table(12) Soil characteristics after conducting the experiment}

\begin{tabular}{|c|c|c|c|c|c|c|c|c|c|c|c|c|}
\hline \multirow{4}{*}{$\begin{array}{l}\text { Physical analysis } \\
\mathrm{EC}(\mathrm{ds} / \mathrm{m}) \\
\mathrm{pH}\end{array}$} & \multicolumn{3}{|c|}{$100 \%$ irrigation water } & \multicolumn{3}{|c|}{$\begin{array}{l}80 \% \text { irrigation water } \\
+20 \% \text { drainage water }\end{array}$} & \multicolumn{3}{|c|}{$\begin{array}{l}50 \% \text { irrigation water } \\
+50 \% \text { drainage water }\end{array}$} & \multicolumn{3}{|c|}{$100 \%$ drainage water } \\
\hline & \multicolumn{3}{|c|}{ Depth in $\mathrm{cm}$} & \multicolumn{3}{|c|}{ Depth in $\mathrm{cm}$} & \multicolumn{3}{|c|}{ Depth in $\mathrm{cm}$} & \multicolumn{3}{|c|}{ Depth in $\mathrm{cm}$} \\
\hline & $0-20$ & $20-40$ & $40-60$ & $0-20$ & $20-40$ & $40-60$ & $0-20$ & $20-40$ & $40-60$ & $0-20$ & $20-40$ & $40-60$ \\
\hline & $\begin{array}{l}1.67 \\
7.76\end{array}$ & $\begin{array}{l}1.78 \\
7.66\end{array}$ & $\begin{array}{l}1.58 \\
7.67\end{array}$ & $\begin{array}{l}1.75 \\
7.85\end{array}$ & $\begin{array}{l}1.84 \\
7.69\end{array}$ & $\begin{array}{l}1.72 \\
7.80 \\
\end{array}$ & $\begin{array}{l}1.81 \\
7.89\end{array}$ & $\begin{array}{l}1.92 \\
7.77\end{array}$ & $\begin{array}{l}1.79 \\
7.52 \\
\end{array}$ & $\begin{array}{l}1.98 \\
7.74\end{array}$ & $\begin{array}{l}2.20 \\
7.76\end{array}$ & $\begin{array}{l}1.91 \\
7.85\end{array}$ \\
\hline \multicolumn{13}{|l|}{ Chemical analysis } \\
\hline $\begin{array}{l}\mathrm{Ca}^{++} \\
\mathrm{Mg}^{++} \\
\mathrm{K}^{+} \\
\mathrm{Na}^{+}\end{array}$ & $\begin{array}{l}4.10 \\
5.10 \\
0.31 \\
7.60\end{array}$ & $\begin{array}{l}4.20 \\
6.72 \\
0.45 \\
7.54\end{array}$ & $\begin{array}{l}4.00 \\
4.63 \\
0.29 \\
6.90\end{array}$ & $\begin{array}{l}4.32 \\
5.20 \\
0.43 \\
6.54\end{array}$ & $\begin{array}{l}4.00 \\
4.92 \\
0.54 \\
6.74\end{array}$ & $\begin{array}{l}3.20 \\
5.60 \\
0.38 \\
6.44\end{array}$ & $\begin{array}{l}4.54 \\
5.60 \\
0.38 \\
7.54\end{array}$ & $\begin{array}{l}4.23 \\
4.54 \\
0.45 \\
7.00\end{array}$ & $\begin{array}{l}3.92 \\
5.67 \\
0.41 \\
6.12\end{array}$ & $\begin{array}{l}4.54 \\
5.45 \\
0.32 \\
6.42\end{array}$ & $\begin{array}{l}5.21 \\
6.52 \\
0.43 \\
7.12\end{array}$ & $\begin{array}{l}3.72 \\
4.87 \\
0.43 \\
7.65\end{array}$ \\
\hline $\begin{array}{l}\mathrm{HCO}_{3}^{\circ} \\
\mathrm{Cl}^{-}\end{array}$ & $\begin{array}{l}1.23 \\
6.57 \\
\end{array}$ & $\begin{array}{l}1.84 \\
7.33 \\
\end{array}$ & $\begin{array}{l}2.20 \\
6.21\end{array}$ & $\begin{array}{l}1.34 \\
6.20\end{array}$ & $\begin{array}{l}1.79 \\
5.64 \\
\end{array}$ & $\begin{array}{l}1.94 \\
4.64\end{array}$ & $\begin{array}{l}1.46 \\
6.67 \\
\end{array}$ & $\begin{array}{l}1.87 \\
5.43\end{array}$ & $\begin{array}{l}2.35 \\
5.68 \\
\end{array}$ & $\begin{array}{l}1.42 \\
6.64\end{array}$ & $\begin{array}{l}1.78 \\
7.81 \\
\end{array}$ & $\begin{array}{l}2.37 \\
6.37\end{array}$ \\
\hline Infilt. rate $\mathrm{cm} / \mathrm{h}$ & \multicolumn{3}{|c|}{0.40} & \multicolumn{3}{|c|}{0.55} & \multicolumn{3}{|c|}{0.58} & \multicolumn{3}{|c|}{0.60} \\
\hline
\end{tabular}

\section{0- The effect of irrigation treatments on tomato yield:}

That the maximum yield was obtained with the MF emitter under the different irrigation water treatment. Emitter KA come to the second place, then the GR emitter and at the end the HO emitter. This effect of using drainage water only is obviously high as the yield decreased for almost $50 \%$ compared with the irrigation water treatment. This means that using drainage water only will effect sharply the growers income.

The different productivity for each treatment in the experiment for every 
type of emitter are shown in table (9).

From Table (10), we find that the relationship between yield, and the Ec of water treatments used in the experiment could be represented with a straight line equation. The MF emitter gave the highest productivity then the KA, GR, finally the $\mathrm{HO}$ emitter. This shows that the tomato crop is affected by the water salinity reflecting on the yield.

\section{1- The soil analysis:}

The soil was chemically, and physically analyzed at the beginning and at the end of conducting the experiments as recommended by FAO paper no. 29 (1985).Table, (11) and (12) show the soil characteristics before and after carrying out the experiments.

Tables (15) and (16) show that the soil physical and chemical characteristics has been affected by the type of water used. While the infiltration rate increased for treatments in which we use the drainage water, and increased as the level of drainage water in the treatment percentage increased, with some slight difference in the chemical analyses. However, the physical analyses showed a difference in the EC values for the different soil layers analyzed due to the different water treatments. And to judge the difference in the rates' of change in the soil needs to execute more experiment, in order to judge the changes in the rates.

\section{CONCLUSION}

We can conclude from the previous study that; we can make use or recycle the drainage water in irrigation of some vegetable crops. The very little damage to the soil and the decrease in the yield also the emitter's kept in a good form obtained with the treatment $80 \%$ irrigation water \& $20 \%$ Drainage water with the MF emitter.

\section{REFERENCE}

Buks, D.A. and S. Davis. (1986), Trickle irrigation for crop production. U.S. Department of Agriculture, Agricultural research service, U.S. Water Conservation Laboratory, Phoenix, Arizona, U.S.A. Chapter 1.,trickle irrigation in crop production, p.1.

Food and Agric. Organization (FAO), (1980). Localized irrigation design, installation, operation, evaluation. FAO irrigation and drainage 
paper (36).

FAO (1985). Water quality in agriculture. FAO Irrigation and drainage paper (29).

FAO/RNEA (1992). Irrigation methods. crops and practices using wastewaters. Tech. Bul., No. 7, p.18.

Hamdy, A. (1999). Sewage water for irrigation, Marginal water management for sustainable irrigation Agriculture in dry area, CIHEAM-MAIB, ICARDA, Aleppo Syria: p. 621

Howell. T. A. and EA Hiller. (1974). Trickle irrigation lateral design. Transactions of the ASAE 17(5):P. 902-908.

Ibrahim, A. Maher (2002). Using of drainge and irrigation water new irrigation method. M. Sc Thesis Theis is Ag. Eng. Alexandria university. (2002).

Karmeli, D. and J. Keller. (1975), Trickle irrigation design. Rain Bird sprinkler manufacturing Corp. Glendora, California, 133p.

Karmeli, D. (1977). Classification and flow regime analysis of drippers. Journal of Agriculture Engineering Research 22: 165-173.

Sharaf, G.A., M.A. Aboamera, and T.K. Zien EI-Abdin. (1998). Effect of treated drainage water on emitter clogging. Misr Journal. Agric. Eng., 15(1):P. 174-182.

Solomon,. K. (1979). Manufacturing variation of trickle emitters. transactions of the ASAE. 22(5):1034-1038,1043.

Von Bernuth, R.D. and K.H. Solomon (1986). Trickle irrigation for crop production. Chapter 2, Design Principles, Emitter construction. U.S. Department of Agriculture,. Agricultural

Wu, I. P. and H. M. Gitlin. (1974). Design of drip irrigation lines. HAES technical bulletin 96, University of Hawaii, Honolulu, 29p.

Wu, I. P. and H. M. Gitlin. (1975). Energy gradient line for drip irrigation laterals. J. Irrig. and Drain. Div., Amer. Soc. Civil Eng. 101 (IR4):321-326. 


\section{الملخص العربى}

تأثير إستخدام خلط مياه الصرف ومياه الرى على نظم الرى بالتنقيط سمير محمد يونس" سعد فتح الله أحمد" مصطفى أبو الخير * أحمد ماهر إبراهيم*"

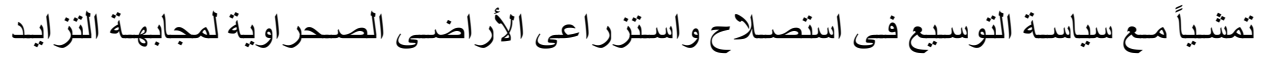

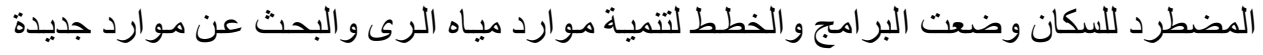

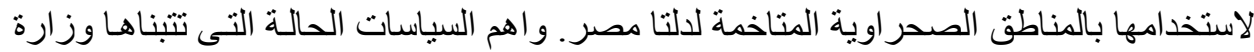
المو ارد المائية و الرى هى خلط مياه الصرف الئن الزر اعى (مياه منخفضة الجودة) بالمياه العذبة (مياه النيل) لتغطية مساحات زر العية الكبر الكبر. لذللك هدفت هذه الدر اسة إلى قياس تأثير نسبة خلط المياه العذبة مع مياه الصرف الزبر اعلى لئى على كل من: ا ـ أداء مكونات نظم الرى الحديثة (موزعات الرى بالتنقيط).

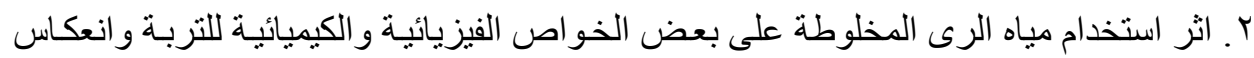

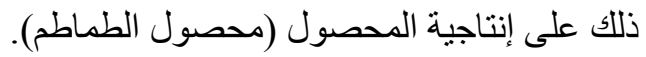

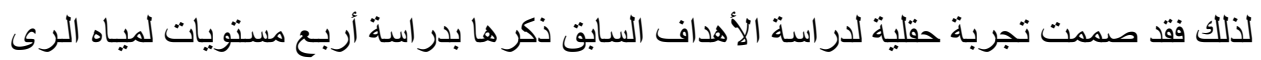

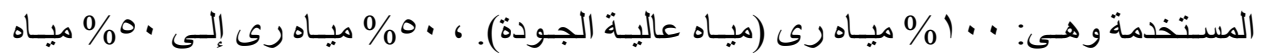

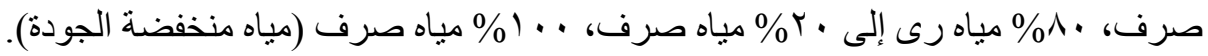

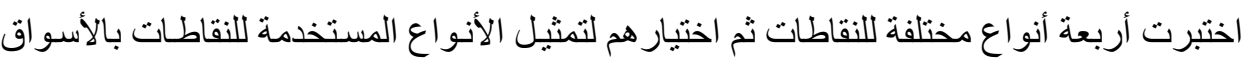

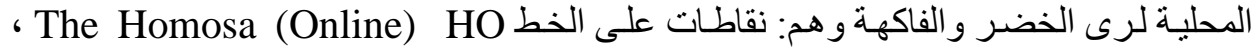

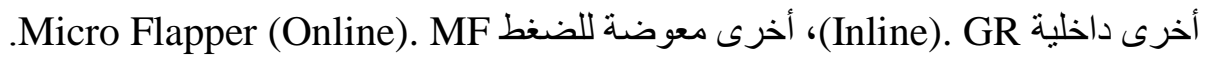

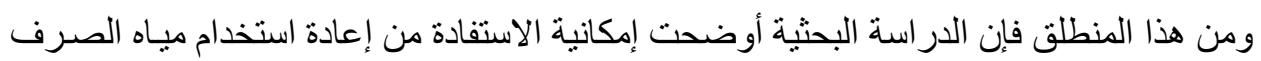

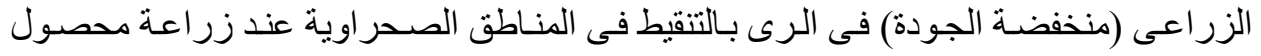

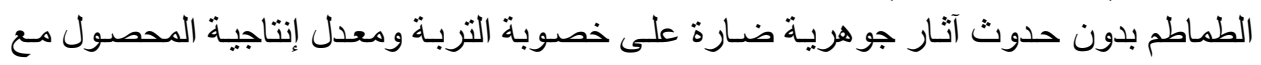

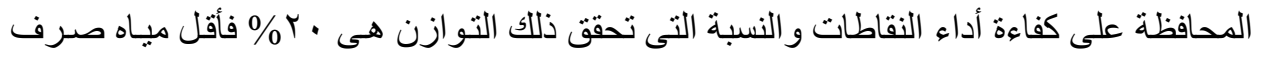

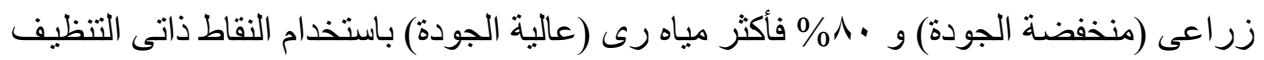

ومعوض للضغط.

قسم الهندسة الزراعية ـ كلية الزراعة ـ جامعة الإسكندرية.

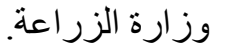

